\title{
GLOSA DO WYROKU WOJEWÓDZKIEGO SĄDU ADMINISTRACYJNEGO W GLIWICACH \\ Z DNIA 17 CZERWCA 2014 R., SYGN. AKT II SA/GL 55/14
}

\section{COMMENTARY TO THE JUDGEMENT OF THE VOIVODESHIP ADMINISTRATIVE COURT IN GLIWICE OF 17 JUNE 2014, II SA/GL 55/14}

http://dx.doi.org/10.12775/PPOS.2014.048

\section{Słowa kluczowe}

Gospodarowanie odpadami; odpady komunalne; administracyjna kara pieniężna.

\section{Keywords} penalty.

Waste management; municipal waste; administrative monetary

\footnotetext{
" Doktor nauk prawnych, Wojewódzki Sąd Administracyjny w Poznaniu.
} 
1. Obowiązek składania sprawozdań kwartalnych, o których mowa w art. 9n ustawy z dnia 13 września 1996 r. o utrzymaniu czystości i porządku w gminach dotyczy tylko tych podmiotów, które faktycznie prowadziły działalność w zakresie odbierania odpadów komunalnych od właścicieli nieruchomości.

2. Kara pieniężna, o której mowa $\mathrm{w}$ art. $9 \mathrm{x}$ ust. 1 pkt 5 ustawy z dnia 13 września 1996 r. o utrzymaniu czystości i porządku w gminach może zostać nałożona tylko na przedsiębiorcę, który miał obowiązek złożenia sprawozdania, o którym mowa w art. 9n ustawy.

Wojewódzki Sąd Adminisistracyjny w Gliwicach w glosowanym wyroku stanął przed koniecznością rozstrzygnięcia, czy podmiot, który choć jest wpisany do rejestru przedsiębiorców prowadzących działalność w zakresie odbierania odpadów komunalnych, to jednak faktycznie nie wykonuje powyższej działalności, jest obowiązany do składania sprawozdań kwartalnych, o których mowa w art. 9n ustawy z dnia 13 września 1996 r. o utrzymaniu czystości i porządku w gminach ${ }^{1}$, a w przypadku zaniechania powyższego obowiązku, czy jest on obowiązany do uiszczenia kary pieniężnej.

Stosownie do treści art. 9n ust. 1 ustawy o utrzymaniu czystości i porządku w gminach podmiot odbierający odpady komunalne od właścicieli nieruchomości jest obowiązany do sporządzania kwartalnych sprawozdań. Sprawozdanie jest przekazywane wójtowi, burmistrzowi lub prezydentowi miasta w terminie do końca miesiąca następującego po kwartale, którego dotyczy (art. 9n ust. 2 powołanej powyżej ustawy). Z kolei, zgodnie z art. 9x ust. 1 pkt o utrzymaniu czystości i porządku w gminach, przedsiębiorca odbierający odpady komunalne od właścicieli nieruchomości, który przekazuje po terminie sprawozdanie, o którym mowa w art. 9n, podlega karze pieniężnej w wysokości 100 zł za każdy dzień opóźnienia. Do kar pieniężnych (art. 9zf o utrzymaniu czystości i porządku w gminach) stosuje się przepisy działu III ustawy z dnia 29 sierpnia $1997 \mathrm{r}$. 
Ordynacja podatkowa ${ }^{2}$, z tym że uprawnienia organów podatkowych przysługują wójtowi, burmistrzowi, prezydentowi miasta oraz wojewódzkiemu inspektorowi ochrony środowiska.

Uważna analiza orzeczeń sądów administracyjnych wskazuje przy tym, że brak jest jednolitego stanowiska, czy na podmiotach, które choć są wpisane do rejestru podmiotów odbierających odpady komunalne, lecz jednak faktycznie nie wykonują powyższej działalności, również spoczywa obowiązek składania kwartalnych sprawozdań. I tak, w wyroku Wojewódzkiego Sądu Administracyjnego we Wrocławiu z dnia 09 stycznia 2014 r. ${ }^{3}$, przyjęto, że na gruncie ustawy z dnia 13 września 1996 r. o utrzymaniu czystości i porządku w gminach należy doszukiwać się obowiązku spoczywającego na podmiocie odbierającym odpady komunalne od właścicieli nieruchomości do sporządzania kwartalnych sprawozdań (art. 9n ust. 1 powołanej powyżej ustawy). W ocenie sądu ustawodawca, kierując przedmiotowy obowiązek do podmiotów odbierających odpady, miał na względzie te podmioty, których działalność jest prowadzona zgodnie z obowiązującymi przepisami, tj. tych, które uzyskały wpis do właściwego rejestru działalności regulowanej w danej gminie. Obowiązek sporządzenia sprawozdania nakierowany został na wszystkie podmioty, które na terenie danej gminy posiadają stosowne uprawnienia do prowadzenia działalności w tym konkretnym zakresie, co powoduje, że sprawozdanie kwartalne musi zostać sporządzone bez względu na fakt, czy odbiór odpadów miał miejsce czy też nie. Jak wynika z przepisów istnieje możliwość złożenia tzw. sprawozdania zerowego, a zatem z prawnego punktu widzenia nie jest istotny faktyczny odbiór odpadów lecz funkcjonowanie danego przedsiębiorcy w rejestrze działalności rejestrowanej prowadzonym przez gminę. Z samej możliwości prowadzenia konkretnej działalności na terenie gminy wynikać będzie obowiązek sprawozdawczy. Podobne stanowisko zajęto w wyroku Wojewódzkiego Sądu Administracyjnego w Krakowie

2 Tekst jedn. Dz.U. z 2012 r., poz. 749 ze zm.

3 Sygn. akt II SA/Wr 691/13, Baza NSA. 
z dnia 18 kwietnia $2014 \mathrm{r}^{4}$, powtarzając argumentację zawartą w wyroku sądu wrocławskiego.

W wyroku Wojewódzkiego Sądu Administracyjnego w Lublinie z dnia 26 marca 2014 r. ${ }^{5}$, stwierdzono z kolei, że za podmiot odbierający odpady komunalne od właścicieli nieruchomości należy uznać przedsiębiorcę wpisanego do rejestru działalności regulowanej, o którym mowa w art. 9b ustawy o utrzymaniu czystości i porządku w gminach bez względu na to, czy w późniejszym okresie odbiera on faktycznie odpady komunalne od właścicieli nieruchomości, czy też nie. Stąd obowiązki sprawozdawcze aktualizują się z momentem wpisu do rejestru, bez względu na to, czy podmiot faktycznie prowadzi działalność $\mathrm{w}$ zakresie objętym wpisem i pozostają aktualne do wykreślenia z rejestru. Choć ustawa o utrzymaniu czystości i porządku w gminach nie określa w sposób jednoznaczny sytuacji podmiotu, który będąc wpisanym do rejestru, nie odbierał w danym kwartale odpadów komunalnych z terenu danej gminy, w szczególności zaś nie zawiera regulacji, iż taki podmiot ma obowiązek składania „sprawozdania zerowego", to jednak ustawa nie reguluje również sytuacji odwrotnej. Nie zawiera też regulacji, z której wynikałoby, że podmiot, który w danym kwartale nie odbierał odpadów komunalnych z terenu danej gminy, jest zwolniony z obowiązku składania sprawozdania. Konsekwentnie podmiot, który w danym kwartale nie odbierał odpadów od właścicieli nieruchomości ma obowiązek złożyć sprawozdanie zerowe według wzoru określonego w rozporządzeniu Ministra Środowiska z dnia 15 maja 2012 r. w sprawie wzorów sprawozdań o odebranych odpadach komunalnych, odebranych nieczystościach ciekłych oraz realizacji zadań z zakresu gospodarowania odpadami komunalnymi ${ }^{6}$, w którym odpowiednie pozycje zawierać wówczas będą wartości zerowe, wykreślenia, względnie inne oznaczenia, z których będzie w sposób niewątpliwy wynikało, iż odpady nie były w ogóle odbierane w danym kwartale. Co charakterystyczne, powołany powyżej wyrok sądu

4 Sygn. akt II SA/Kr 256/14, Baza NSA.

5 Sygn. akt I SA/Lu 1371/13, Baza NSA.

6 Dz.U. z 2012 r., poz. 630. 
lubelskiego pokrywa się ze stanowiskiem zajmowany przez Departament Gospodarowania Odpadami Ministerstwa Środowiska, zgodnie z którym skoro ustawa nie określa w sposób jednoznaczny, że podmiot, który w danym kwartale nie odebrał odpadów komunalnych $\mathrm{z}$ terenu danej gminy jest zwolniony z obowiązku składania sprawozdania, to ma on obowiązek złożyć tzw. sprawozdanie zerowe lub informację do wójta, burmistrza, prezydenta miasta o nieodebraniu odpadów z terenu gminy w danym kwartale ${ }^{7}$.

Glosowany wyrok odbiega od powołanych powyżej orzeczeń sądów administracyjnych oraz stanowiska zajmowanego przez organy administracji, przyjmując pogląd, zgodnie z którym obowiązek składania sprawozdań kwartalnych, o których mowa w art. 9n ustawy o utrzymaniu czystości i porządku w gminach dotyczy tylko tych podmiotów, które faktycznie prowadziły działalność w zakresie odbierania odpadów komunalnych od właścicieli nieruchomości. Odniesienie się do podnoszonych w nim argumentów wymaga jednak w pierwszej kolejności scharakteryzowania obowiązującego obecnie systemu odbierania odpadów komunalnych na terenie gminy.

Jak wyjaśniono $\mathrm{w}$ uzasadnieniu projektu ustawy z dnia 01 lipca 2011 r. o zmianie ustawy o utrzymaniu czystości i porządku w gminach oraz niektórych innych ustaw ${ }^{8}$, zastąpienie istniejącego dotychczas zezwolenia na odbieranie odpadów komunalnych od właścicieli nieruchomości obowiązkiem wpisu przedsiębiorcy zajmującego się tego typu działalności do rejestru działalności regulowanej, w rozumieniu ustawy z dnia 2 lipca 2004 r. o swobodzie działalności gospodarczej ${ }^{9}$ miało przyczynić się do zwiększenia wolności działalności gospodarczej w Polsce w zakresie odbierania odpadów komunalnych od właścicieli nieruchomości. Samo wprowadzenie regulacji doty-

7 http://www.mos.gov.pl/artykul/4810_sprawozdawczosc/20070_sprawozdanie_zerowe_podmiotu_ktory_posiada-wpis_do_rejestru_a_nie_prowadzi_odbierania_odpadow_komunalnych.html, data pobrania: 10 października 2014 r.

8 Druk sejmowy Sejmu RP VI Kadencji nr 3670.

9 Tekst jedn. Dz.U. z 2013 r., poz. 672 ze zm. 
czącej spoczywających na przedsiębiorcach obowiązków z zakresu sprawozdawczości w ocenie ustawodawcy miało umożliwić gminom skuteczniejszą kontrolę przestrzegania przepisów ustawy o utrzymaniu czystości i porządku w gminach. Równocześnie, jak podniesiono $\mathrm{w}$ uzasadnieniu projektu ustawy, w celu zmotywowania poszczególnych podmiotów, biorących udział w systemie gospodarowania odpadami komunalnymi do przestrzegania zasad określonych przedmiotową ustawą oraz do osiągnięcia wyznaczonych nią celów wójt, burmistrz lub prezydent miasta uzyskał kompetencję do nałożenia administracyjnej kary pieniężnej, w drodze decyzji, na przedsiębiorcę odbierającego odpady komunalne od właścicieli nieruchomości, w przypadku gdy m.in. przekaże on sprawozdanie z realizacji zadań po terminie. O ile więc ustawodawca wskazał ogólne reguły wykładni dotyczące przepisów z zakresu kar administracyjnych, wyjaśniając, że ich nałożenie jest bezpośrednio związane z koniecznością zapewnienia skuteczności wprowadzonego systemu gospodarowania odpadami, o tyle nie wyjaśnił, czy przedsiębiorca, który choć jest wpisany do rejestru działalności regulowanej, w związku z zamiarem podjęcia działalności polegającej na odbiorze odpadów komunalnych, jednakże faktycznie nie prowadzi powyższej działalności, jest obowiązany do składania sprawozdań kwartalnych. W przepisie art. 9x ust. 1 ustawy o utrzymaniu czystości i porządku w gminach wyjaśniono jedynie, że przedsiębiorca odbierający odpady komunalne od właścicieli nieruchomości, który przekazuje po terminie sprawozdanie, o którym mowa w art. 9n, podlega karze pieniężnej w wysokości 100 zł za każdy dzień opóźnienia. Podkreślenia jednak wymaga, że choć w ustawie o utrzymaniu czystości i porządku w gminach nie ma przepisu, który zwalniałby z obowiązku złożenia sprawozdania w przypadku podmiotu nie świadczącego usług w zakresie zbierania odpadów komunalnych, to jednak wbrew twierdzeniom Ministerstwa Środowiska w ustawie brak jest również przepisu, który nakazywałby składanie sprawozdań „zerowych” czy też oświadczeń o nie zbieraniu odpadów komunalnych.

Wojewódzki Sąd Administracyjny w Gliwicach w glosowa4/2014 nym wyroku, przyjmując, że obowiązek składania sprawozdań 
kwartalnych, o których mowa w art. 9n ustawy o utrzymaniu czystości i porządku w gminach dotyczy tylko tych podmiotów, które faktycznie prowadziły działalność w zakresie odbierania odpadów komunalnych od właścicieli nieruchomości, odwołał się do wykładni językowej, wyjaśniając, że użycie w art. 9n ustawy o utrzymaniu czystości i porządku w gminach określenie „odbierający” wskazuje, że jest ono równoważne z określeniem „ten, który odbiera”. Stąd, zdaniem sądu, powołany powyżej przepis art. 9n ustawy o utrzymaniu czystości i porządku w gminach odnosi się do podmiotów, które faktycznie odbierają (w danym okresie sprawozdawczym) odpady od właścicieli nieruchomości. Zwrócono przy tym uwagę, że sam wpis do rejestru, o jakim mowa w art. 9c ustawy o utrzymaniu czystości i porządku w gminach nie może skutkować uznaniem wpisanego tam podmiotu jako „odbierającego odpady”, gdyż rejestr powyższy stanowi jedynie formę ułatwienia prowadzenia działalności gospodarczej w zakresie odbierania odpadów komunalnych.

Następnie sąd wskazał na zasady wykładni celowościowej art. 9n w związku z art. 9x ustawy o utrzymaniu czystości i porządku w gminach, wyjaśniając, że celem przewidzianej w ustawie sankcji jest wymuszenie na przedsiębiorcach prowadzących działalność w zakresie odbierania odpadów komunalnych od właścicieli nieruchomości postępowania zgodnego z prawem. Niczym nieuzasadnione jest więc jej stosowanie wobec podmiotów, które takiej działalności nie prowadzą. Wymaganie od tych ostatnich składania sprawozdań, o których mowa w art. 9n ustawy o utrzymaniu czystości i porządku w gminach, a w konsekwencji wymierzanie kar pieniężnych, o których mowa w art. 9x ustawy, stanowi w opinii sądu niedopuszczalną wykładnię rozszerzającą przepisy o charakterze sankcyjnym.

Reasumując powyższe ustalenia, sąd uznał, iż obowiązek składania sprawozdań kwartalnych, o których mowa w art. 9n ustawy o utrzymaniu czystości i porządku w gminach dotyczy tylko tych podmiotów, które faktycznie prowadziły działalność w zakresie odbierania odpadów komunalnych od właścicieli nieruchomości. W konsekwencji należało przyjąć, że kara pieniężna, o której mowa w art. 9x ust. 1 pkt 5 ustawy o utrzymaniu czystości i porządku w gminach może zostać nałożona tylko 
na przedsiębiorcę, który miał obowiązek złożenia sprawozdania, o którym mowa w art. 9n ustawy, a więc który faktycznie prowadził działalność polegającą na obiorze odpadów.

Odnosząc się do powyższego stanowiska Wojewódzkiego Sądu Administracyjnego w Gliwicach, należy podzielić stanowisko, że w świetle przytoczonego uzasadnienia zmian w ustawie o utrzymaniu czystości i porządku w gminach wprowadzenie obowiązku uzyskania wpisu do rejestru działalności stanowiło przejaw ułatwienia prowadzenia działalności regulowanej w zakresie odbierania odpadów komunalnych. Choć ustawodawca uznał, że działalność powyższa powinna mieć charakter regulowany, to jednak postanowił przyjąć formę najmniej uciążliwą dla przedsiębiorcy, w postaci konieczności uzyskania wpisu do rejestru działalności regulowanej, o jakiej mowa w art. 5 pkt 5 ustawy z dnia 2 lipca 2004 r. o swobodzie działalności gospodarczej ${ }^{10}$. W odróżnieniu od innych sposobów reglamentacji gospodarczej - koncesji oraz zezwolenia - poza złagodzonymi warunkami, jakie muszą być spełnione dla rozpoczęcia działalności regulowanej, ustawodawca nie nakłada na podmiot chcący wykonywać działalność regulowaną obowiązku jej podjęcia. W praktyce możliwe jest więc powstanie sytuacji, w której podmiot uzyska wpis do rejestru działalności regulowanej, a jednak nie rozpocznie faktycznego jej wykonywania. Zasadnie sąd, w glosowanym wyroku, wskazuje więc w odwołaniu do reguł wykładni językowej, że nie można utożsamiać pojęcia "odbierania odpadów" do wszystkich podmiotów, które uzyskały wpis do rejestru działalności regulowanej, gdyż odbieraniem odpadów będą zajmowały się jedynie podmioty, które uzyskały stosowny wpis do rejestru i faktycznie podejmują tego rodzaju działalność.

Zauważyć jednak należy, że w uzasadnieniu projektu ustawy o utrzymaniu czystości i porządku w gminach wprost wyjaśniono, że złagodzeniu wymogów dotyczących podmiotów prowadzących działalność w zakresie odbioru odpadów towarzyszyło wprowadzenie regulacji dotyczącej spoczywających na przedsiębiorcach obowiązków z zakresu sprawozdawczości, co

10 Tekst jedn. Dz.U. z 2013 r., poz. 672 ze zm. 
miało przyczynić się do skuteczniejszej kontroli przestrzegania przepisów ustawy o utrzymaniu czystości i porządku w gminach. Z tego punktu widzenia, faktycznie, jak prawidłowo przyjął sąd, istotne znaczenie dla ustalenia kręgu podmiotów, na jakich spoczywa obowiązek dostarczenia sprawozdań kwartalnych ma przyjęcie, które podmioty faktycznie wykonują działalność w zakresie odbierania odpadów komunalnych.

W tym miejscu podkreślenia wymaga, że w niektórych orzeczeniach sądów administracyjnych zauważa się, że gmina każdorazowo posiada wiedzę o podmiotach prowadzących tego typu działalność. I tak, w wyroku Wojewódzkiego Sądu Administracyjnego w Warszawie z dnia 27 lutego $2014 \mathrm{r}^{11}$ zauważono, że skoro celem ustanowienia obowiązku sprawozdawczego było przedstawienie obrazu postępowania z odpadami, ich odzyskiem, recyklingiem, to w przypadku podmiotów nie prowadzących w danej gminie tego typu działalności obowiązek powyżej jest bezprzedmiotowy, gdyż pozostaje obojętny dla celu zamierzonego przez ustawodawcę. Gmina prowadząca szczegółową ewidencję dotyczącą gospodarowania odpadami ma pełną wiedzę na temat podmiotów rzeczywiście świadczących usługi na jej terenie, gdyż przeprowadza w tym zakresie obowiązkowe przetargi wyłaniające wykonawców odbierających odpady komunalne, zawiera z nimi umowy i prowadzi dodatkowo rejestr tych umów. Stąd obowiązek składania kwartalnych sprawozdań nie dotyczy podmiotów jedynie pretendujących do zawarcia umowy z gminą lecz podmiotów faktycznie świadczących powyższe usługi w oparciu o stosowną umowę. Natomiast sama okoliczność zgłoszenia i uzyskania wpisu danego podmiotu do gminnego rejestru działalności regulowanej w zakresie odbierania odpadów, w sytuacji gdy na terenie tej gminy podmiot nie prowadził i nie prowadzi działalności, nie stanowi o obowiązku składania sprawozdań, o jakich mowa w art. 9n ust. 1 ustawy o utrzymaniu czystości i porządku w gminach.

Uważna lektura przepisów ustawy o utrzymaniu czystości i porządku w gminach wskazuje, że możliwe jest powstanie sytuacji, gdzie dany podmiot wykonuje działalność polegającą na

11 Sygn. akt IV SA/Wa 2694/13, Baza NSA. 
odbiorze odpadów komunalnych, jednak nie działa on w oparciu o umowę zawartą z gminą. W przepisie art. 9h powołanej powyżej ustawy wskazano bowiem, że podmiot odbierający odpady komunalne od właścicieli nieruchomości, który nie działa na podstawie umowy zawartej z gminą i nie świadczy takiej usługi w trybie zamówienia z wolnej ręki, jest obowiązany przekazać właścicielom nieruchomości, od których odbiera odpady komunalne, rachunek, w którym są wyszczególnione koszty odbierania i zagospodarowania odpadów komunalnych. Regulacja powyższa jest powiązana bezpośrednio z art. 6c ustawy o utrzymaniu czystości i porządku w gminach, gdzie wskazano wprost, że gminy są obowiązane do zorganizowania odbierania odpadów komunalnych od właścicieli nieruchomości, na których zamieszkują mieszkańcy (art. 6c ust. 1 ustawy o utrzymaniu czystości i porządku w gminach), przy czym rada gminy może, w drodze uchwały stanowiącej akt prawa miejscowego, postanowić o odbieraniu odpadów komunalnych od właścicieli nieruchomości, na których nie zamieszkują mieszkańcy, a powstają odpady komunalne (art. 6c ust. 2 ustawy o utrzymaniu czystości i porządku w gminach). A więc mogą istnieć na terenie gminy obszary, na których odpady komunalne nie są zbierane przez podmioty działające na podstawie umów zawartych $\mathrm{z}$ gminą.

Co charakterystyczne, okoliczność powyższa znajduje swoje odzwierciedlenie również w art. 9n ustawy o utrzymaniu czystości i porządku w gminach, gdzie w ust. 4 wskazano, że podmiot odbierający odpady komunalne od właścicieli nieruchomości, który nie działa na podstawie umowy, o której mowa w art. $6 \mathrm{f}$ ust. 1 , i nie świadczy takiej usługi w trybie zamówienia z wolnej ręki, o którym mowa w art. 6f ust. 2, jest zobowiązany zamieścić w sprawozdaniu także informacje o osiągniętych poziomach recyklingu, przygotowania do ponownego użycia i odzysku innymi metodami oraz ograniczenia masy odpadów komunalnych ulegających biodegradacji przekazywanych do składowania. Ponadto, stosownie do treści art. 9n ust. 5 ustawy, podmiot powyższy jest zobowiązany do załączenia do sprawozdania wykazu właścicieli nieruchomości, z którymi w okresie objętym sprawozdaniem zawarł umowy na odbieranie odpa- 
dów komunalnych oraz wykaz właścicieli nieruchomości, z którymi umowy te uległy rozwiązaniu lub wygasły. W wykazach zamieszcza się imię i nazwisko albo nazwę oraz adres właściciela nieruchomości, a także adres nieruchomości. Oznacza to, że gmina nie zawsze musi mieć wiedzę o podmiotach, które rzeczywiście prowadzą działalność w zakresie odbioru odpadów komunalnych, co ma miejsce w sytuacji, gdy nie działa na podstawie umowy zawartej z gminą i nie świadczy takiej usługi w trybie zamówienia z wolnej ręki. W konsekwencji zaaprobowanie stanowiska zaprezentowanego przez Wojewódzki Sąd Administracyjny w Gliwicach mogłoby prowadzić do powstania sytuacji, w której podmiot wpisany do rejestru działalności regulowanej, odbierający odpady, o jakich mowa w art. art. 6c ust. 2 ustawy o utrzymaniu czystości i porządku w gminach, pozostawałby poza jakąkolwiek kontrolą wójta, burmistrza lub prezydenta miasta, albowiem organy te nie wiedziałyby o powyższym fakcie z uwagi na to, że nie złożyłby on stosownego sprawozdania. Taka wykładnia sprzeciwia się celowi ustawy, którym jak już powyżej wskazano, jest skuteczniejsza kontrola przestrzegania przepisów ustawy o utrzymaniu czystości i porządku w gminach.

W tym miejscu należy zauważyć, że przepis art. 9x ust. 1 pkt. 1 ustawy o utrzymaniu czystości i porządku w gminach penalizuje działanie polegające na odbiorze odpadów komunalnych bez wymaganego wpisu do rejestru działalności regulowanej. Niewątpliwie powyższe brzmienie powołanego powyżej przepisu wskazuje, że ustawodawca posługując się sformułowaniem „przedsiębiorca odbierający odpady komunalne od właścicieli nieruchomości" miał na uwadze podmiot rzeczywiście świadczący tego rodzaju usługi na terenie gminy, a nie podmiot jedynie wpisany jako uprawniony do rejestru działalności regulowanej. Również sankcja polegająca na wymierzeniu kary pieniężnej z tytułu braku terminowego przekazania sprawozdania spoczywa na „przedsiębiorcy odbierającym odpady komunalne". Jednakże w świetle powołanych powyżej argumentów nie sposób przyjąć, aby katalog tych podmiotów był tożsamy.

Niewątpliwie redakcja art. 9x ust. 1 pkt 5 ustawy o ustawy o utrzymaniu czystości i porządku w gminach, z uwagi na 
powstałe wątpliwości interpretacyjne jest wadliwa, i de lege ferenda postulować należy jej zmianę, poprzez doprecyzowanie, że obowiązek złożenia sprawozdania spoczywa na przedsiębiorcach wpisanych do rejestru działalności regulowanej, o jakim mowa w ustawie. Niemniej jednak w obecnym stanie prawnym przyjąć należy, że kara pieniężna, o której mowa w art. 9x ust. 1 pkt 5 ustawy o utrzymaniu czystości i porządku w gminach może zostać nałożona tylko na przedsiębiorcę, który miał obowiązek złożenia sprawozdania, o którym mowa w art. 9n powołanej powyżej ustawy, przy czym przedsiębiorcą powyższym jest zawsze podmiot, który uzyskał wpis do rejestru działalności regulowanej. Obowiązek składania sprawozdań kwartalnych, dotyczy wszystkich podmiotów, które uzyskały wpis i nie jest zależny od tego, czy podmioty te faktycznie prowadziły działalność w zakresie odbierania odpadów komunalnych od właścicieli nieruchomości.

Kontakt e-mail:

pawel.daniel@wp.pl 